\title{
ANCIENT EGYPTIAN AGRICULTURE AND THE ORIGINS OF HORTICULTURE
}

\author{
Jules Janick \\ Department of Horticulture and Landscape Architecture \\ Purdue University \\ West Lafayette, Indiana 47907, USA
}

The story of Egypt leads us to the dawn of history. Paleolithic-Neolithic artifacts (flint hand-axes, arrowheads, hammers) along the Nile date back 12,000 years. Nubian, Ethiopian, and Libyan populations fusing with Semitic and West Asian immigrants formed a people and created the Egypt of history (Durant, 1954). A continuous 6000 year record exists (Table 1) with a unique and productive agriculture at its base. From 4000 to 3000 все these mingled peoples of the Nile valley formed a government, constructed the first pyramids, and established a highly advanced agricultural technology. The ancient names for Egypt underscore the relation between the land, the people, and it agriculture (Khattab, 2000). These include Ta-meri, the beloved land cultivated by the hoe, Ta Akht, the land of flood and fertile soil, Kmt, the black soil, Tamhi, the land of the flax plant, Nht, the land of the sycomore fig tree, and Misr, the safe and civilized country. The name, Egypt, was derived from the name of the Earth God, Ge, or from Agpt, referring to the land covered with flood waters.

Knowledge of the history of Egyptian agriculture and horticulture can be gleaned from the archeological record supported by surviving written Egyptian documents, temple inscriptions, and commentaries from antiquity including those of the Greek historian Herodotus (484-425 вСЕ), the philosopher Theophrastus (372-288 вСE), and the book of Genesis in the Hebrew bible. The supporting technology can be vividly reconstructed from the artistic record, painted and carved in tombs and temples dating from before 3000 вСE. Agricultural activities were favorite themes of artists who drew or sculpted lively scenes of daily life that adorn the tombs of the pharaohs. Illustrations of these artifacts and artistic works found in two key references, Food, Gift of Osiris (Darby et al., 1974) and Volume I of A History of Technology (Singer et al., 1954) have been used for this paper supplemented by other sources (Janick, 1979), as well as some personal photographs by the author.

The development of Egyptian agriculture did not occur in a vacuum. Egypt was an aggressive culture and, at one time, Egypt ruled from present day Libya in the West, Syria in the Northeast, and Ethiopia and Somalia and, perhaps, portions of sub-Saharan Africa in the south. Egypt continuously incorporated technology as well as new crops from the Fertile Crescent (present day Israel, Jordan, Lebanon, Syria, and Iraq) as well as Africa. In addition there were contacts with the world beyond including Africa, Western Asia, and, even China. Strands of silk have been found on mummies of the Pharaohs dating to about $1000 \mathrm{BCE}$, indicating an ancient exchange of spices and fabrics. A stream of immigrants and captives, as well as invasions by others, such as the Persians in 525 вСE, also contributed to new introductions of germplasm and technology.

To explain the unknown the Egyptians created a complex and bewildering theology that drew on the sun and the sky as well every form of life, and later included a pantheon of human gods and goddesses. Their beliefs greatly influenced the ancient world and has since been incorporated into many present day religions. Egyptian understanding and knowledge of plant and animal life was incorporated into both religious beliefs and art. Thus, papyrus, the symbol of lower Egypt, and the lotus, the symbol of upper Egypt, were incorporated in numerous paintings of hunting scenes, floral offerings, as well as the architectural designs of columns (Fig. 1A,B,E,F). The unification of upper and lower Egypt is expressed not only by the fused hats of the pharaohs but also by the ceremonial intertwining of the two plants (Fig. 1C,D) 
Table 1. Egyptian chronology. Source: Darby et al. 1976; Singer et al. 1954.

\begin{tabular}{|c|c|c|}
\hline Period & Time frame & Event \\
\hline $\begin{array}{l}\text { Paleolithic-Neolithic } \\
\text { (Pre-dynastic) }\end{array}$ & $10,000-4000$ ВСЕ & Agricultural beginnings \\
\hline $\begin{array}{l}\text { Old Kindgom } \\
\text { (I-VI dynasty) }\end{array}$ & $3500-2631$ & $\begin{array}{l}\text { Government; Earliest pyramids; Reunification of } \\
\text { upper and lower Egypt (3200 вСE); King Zozer } \\
\text { (3150 вСЕ); Inhotep, physician. }\end{array}$ \\
\hline $\begin{array}{l}\text { Middle Kingdom } \\
\text { (XI-XIV) }\end{array}$ & $2375-1800$ & \\
\hline $\begin{array}{l}\text { Empire, New Kingdom } \\
\quad(\mathrm{XVII}-\mathrm{XX})\end{array}$ & $1580-1100$ & $\begin{array}{l}\text { Queen Hatsepsut; Moses (ca. 1500); King Tut- } \\
\text { Annkh-Amen (1350 вCE); Rameses I, II } \\
\text { (1300 вCE) }\end{array}$ \\
\hline $\begin{array}{l}\text { Saite, Late Period } \\
\quad(\text { XXVI) }\end{array}$ & $663-525$ & \\
\hline Persian & 525-332 (interrupted) & \\
\hline Graeco-Roman & 332 BCE-305 CE & $\begin{array}{l}\text { Alexander (332-323); Ptolemies, } 14 \text { kings } \\
\quad(323-344 \text { BCE); Cleopatra (51-30 BCE) }\end{array}$ \\
\hline Byzantine & $305-642$ & \\
\hline Arabic & $642-1517$ & \\
\hline Turkish & $1517-1804$ & \\
\hline Modern & 1804-present & $\begin{array}{l}\text { Mohamed Aly dynasty (1804-1952); } \\
\text { Republic (1952-present) }\end{array}$ \\
\hline
\end{tabular}

\section{Crop Plants}

Knowledge of crops of ancient Egypt can be deduced from the artistic record but definite proof comes from the desiccated remains of plants themselves. Many archeological remnants of both plants and animals can be viewed in the newly reconstructed Ancient Egyptian Agricultural Museum in Cairo.

The chief ancient grain crops, used for bread and beer, were barley and various wheats including the diploid einkorn, (AA genome), the tetraploid emmer and durum wheats (AABB), and the hexaploid spelt and bread wheats (AABBDD). One of the ancient cereals of Egypt classified as Triticum turgidum (AABB) now marketed as Kamut ${ }^{\circledR}$ has recently been introduced to the United States.

The vegetable crops of ancient Egypt included a number of root crops, leafy salad crops, legumes, and various cucurbits. The ancient root crops such as the pungent alliums, garlic (Allium sativum) and onion (A. cepa), as well as radish (Raphanus sativum) continue to be very popular in modern Egypt. Among the leafy salad crops were lettuce, (Lactuca sativa) and parsley (Petroselinum crispum). There were a number of pulses such as cowpea (Vigna sinensis), faba (broad) bean (Vicia fava), chickpea (Cicer arietinum), and lentils (Lens culinaris). The cucurbits included cucumber (Cucurbita sativa), melons and gourds (Cucumis melo), and later watermelon (Citrullus lanatus).

The fruit crops of Egypt were expanded throughout the centuries (Table 2). The date and doum palm as well as the sycomore fig are considered pre-dynastic Egyptian fruits although the sycomore is not indigenous. The jujube, fig, and grape were known since the Old Kingdom (Table 2), the carob and pomegranate were introduced in the Middle Kingdom; the olive and apple appear in the new Kingdom; and the peach and pear date to the Graeco-Roman period. 
A

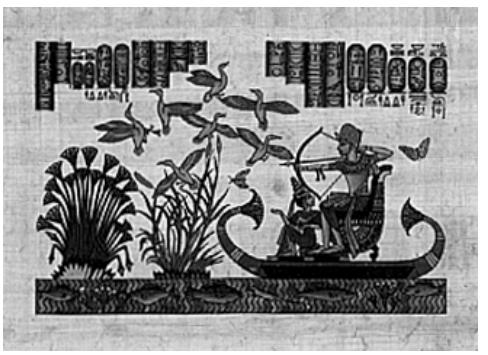

B

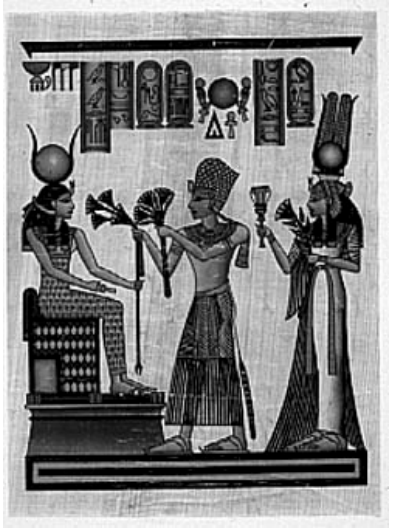

C

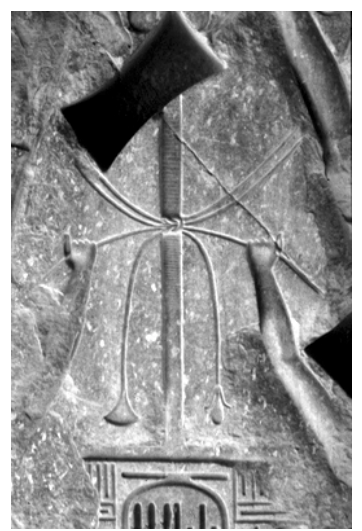

D

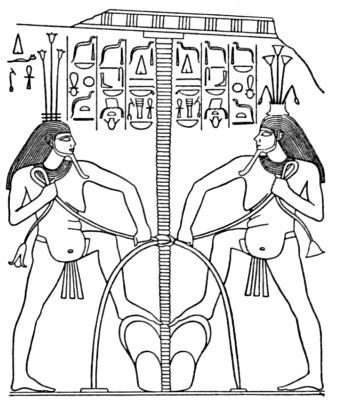

$\mathbf{F}$

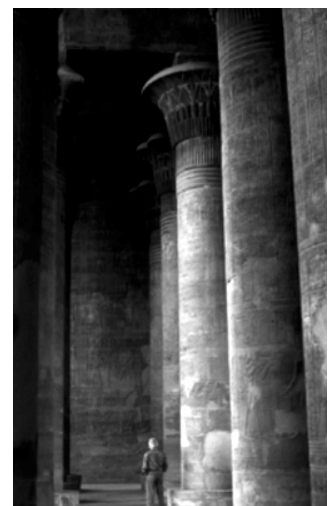

Fig. 1. Papyrus and lotus symbols of upper and lower Egypt.

A. Hunting scene showing lotus and papyrus

B. Offering of lotus and papyrus to Isis.

C. and D. Intertwining of lotus and papyrus symbolizing the reunification of upper and lower

Egypt. Source: (C) Cairo museum, J. Janick photo, (D) Throne of Semuscret I. 1900 BCE,

Singer et al., 1954, Fig. 28.

E. and F. The Temple of Khnum (Kom Ombo), at Esna showing columns representing papyrus and lotus (J. Janick photo)

About 2000 species of flowering and aromatic plants have been found in tombs. An exquisite bas relief, depicting a visual representation of the fragrance from essential oils being extracted from an herb, is found on the walls of the Philae Temple (Fig. 2A). Herb and spice plants important for culinary, cosmetic, medicinal, and religious uses including embalming were continually introduced. In the 15 century вСE, Queen Hatshepsut recorded the details of her expedition to Punt to fetch myrrh and spices (see Fig. 10). The story in the book of Genesis of the spice-trading Israelites, who bought Joseph from his brothers still resonates in the popular theatre (e.g., Joseph and the Amazing Technicolor Dreamcoat). Herbs, spices, aromatics, and medicinal plants include ami or Ethiopian cumin (Carum copticum), anise (Pimpinella asisum), caper (Capparis spinosa), coriander (Coriandrum sativum), cumin (Cuminum cyminum), dill (Anethum graveolens), fennel (Foeniculum vulgare), fenugreek (Trigonella foenum graecum), marjoram (Origanum majorana), mint (Mentha spicata, M. sativa), mustard (Sinapis alba), rosemary (Rosmarinus officinalis), safflower (Carthamnus tinctorius), thyme (Thymus acinos), and pomegranate root. 
Table 2. Evidence for fruit crops in Egypt. Source: Adapted from Darby et al., 1976

\begin{tabular}{llll}
\hline Common name & Scientific name & $\begin{array}{c}\text { Earliest record } \\
\text { (dynasty or period) }\end{array}$ & Type of evidence \\
\hline Date palm & Phoenix dactylifera & Pre-dynastic & Archeological \\
Doum palm & Hyphaene thebaica & Pre-dynastic & Archeological \\
Sycomore fig & Ficus sycomorus & Pre-dynastic & Archeological \\
Jujube (Christ's thorn) & Ziziphus spina-Christi & I (Old Kingdom) & Archeological \\
Fig & Ficus carica & II (Old Kingdom) & Artistic \\
Grape & Vitis vinifera & II (Old Kingdom) & Archeological \\
Hegelig & Balanites aegyptiaca & III (Old Kingdom) & Archeological \\
Persea (lebakh) & Mimusops shimperi & III (Old Kingdom) & Archeological \\
Argun palm & Medemia argun & V (Old Kingdom) & Archeological \\
Carob* & Ceratonia siliqua & XII (Middle Kingdom) & Archeological \\
Pomegranate & Punica granata & XII (Middle Kingdom) & Archeological \\
Egyptian plum & Cordia myxa & XVIII (New Kingdom) & Archeological \\
(sehestem, mokheit) $)$ & & \\
Olive & Olea europea & XVIII (New Kingdom) & Archeological \\
Apple & Malus $\times$ domestica & XVIIII (New Kingdom) & Literary \\
Peach & Prunus persica & Graeco-Roman & Archeological \\
Pear & Pyrus communis & Graeco-Roman & Archeological \\
Cherry & Prunus avium; & 5 BCE & Literary \\
Citron & P. cerasus & & \\
\hline
\end{tabular}

* A questionable literary reference dates to the first dynasty

Industrial and fiber crops were important in ancient Egypt. Oil of the castor bean (Ricinus communis) was used for illumination and also as a medicinal, flax (Linum usitatissimum) for linen and oil, henna (Lawsonia inermis) for dye, papyrus (Cyperus papyrus) for paper and medicinal use, aquatic lotus (Nymphaea lotus and N. caerulea) for seed and decoration, and acacias (Acacia spp.) for gums and oils.

The ancient Egyptians loved flowers as evidenced by murals portraying court ladies wearing Egyptian lotus blooms, container-grown plants, and funeral garlands. Rameses III (1198$1166 \mathrm{BCE}$ ) founded pleasure grounds with "wide places for walking with all kinds of sweet fruit trees, laden with fruit, a sacred way, beautiful with flowers of all lands." Small shrubs were grown in large earthenware pots, the forerunner of our potted plant industry (Huxley, 1978, 1998). Plant dyes were an important part of the cosmetic arts (Fig. 2B) and aromatic ingredients from flowers (Fig. 2C,D) were incorporated into oils and fats for use in perfumes, unguents, and ointments (Fig. $2 \mathrm{E})$.

\section{Irrigation and Drainage Technology}

The Nile valley dictated the agriculture of ancient Egypt. Long stretches of flat lands were bordered by perpendicular mountains and inundated by constant rhythmic seasonal flooding. The Greek historian Herodotus (484-425 вСЕ) described Egypt as "a rainless area but extremely fertile. Egypt is the gift of the Nile."

Egypt gave the world the first hydraulic engineering and systematic irrigation (Fig. 3). The Nile rises and falls with regularity, rising in July (canals were opened August 22) and contin- 
$\mathbf{A}$

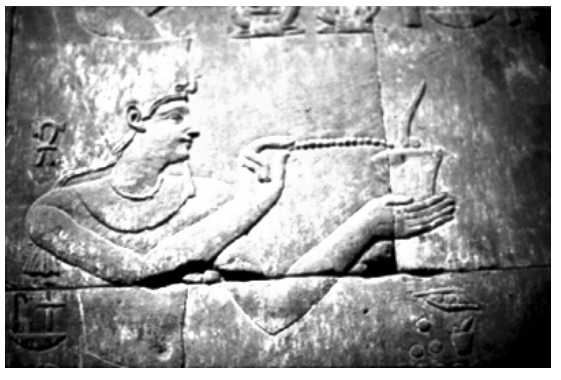

C

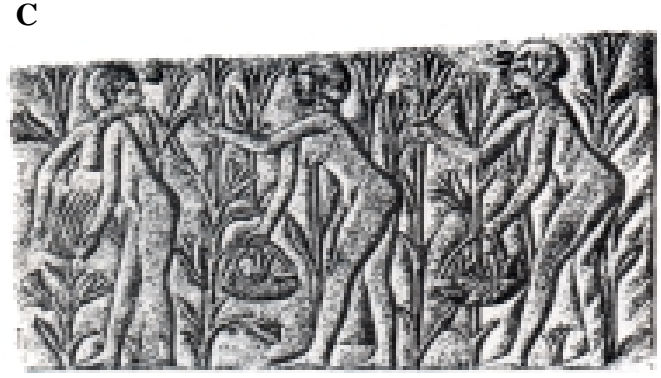

B

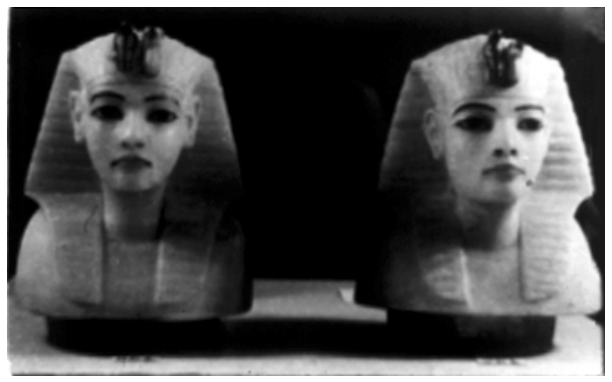

D

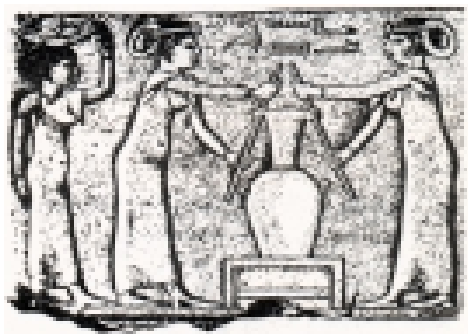

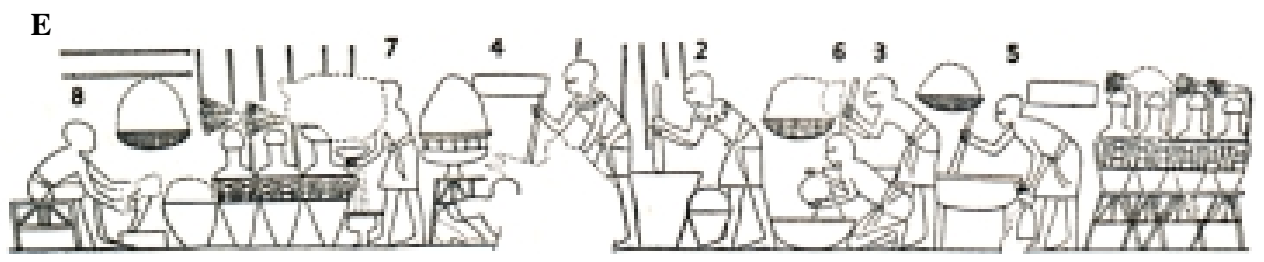

Fig. 2. Perfume and cosmetics.

A. A visual representation of the fragrance from essential oils being extracted from an herb. Philae Temple (dismantled and reassembled on Agilika Island, about $500 \mathrm{~m}$ from its original home), Aswan. (J. Janick, photo).

B. Cover of alabaster Canopic Vase in Tut Ankh Amon. Note lipstick and painted eyes.

C. Gathering lilies for their perfume. Source: Singer et al., 1954, Fig. 189.

D. Expressing oil of lily. Source: Singer et al., 1954, Fig 189.

E. Compounding ointments and perfumes. Assistants crush dried herbs with pestle and mortar $(1,2,3,4)$. The crushed herbs are added to a bowl of molten fat, stirred (5) and shaped into balls upon cooling (6). Special jars probably containing spiced wine, a useful solvent because of its alcohol content is siphoned and filtered into a bowl (7). At extreme left an assistant shapes a piece of wood beneath a bowl heaped with unguents. Tomb at Thebes, ca. 1500 BCE Source: Singer et al., 1954, Fig 190.

ues to rise until the middle of October, and then rapidly subsides. Crops were sown in November and harvested in April and May (Singer et al., 1954). Basin irrigation, the basic system, consisted of a system of dikes to retain the flood and encourage infiltration of the soil. Earthen banks paralleled the river while intersecting banks created a checkerboard of dike-enclosed areas, between 400 and 16,000 hectares each. Canals led the water to areas difficult to inundate. The flood 
A

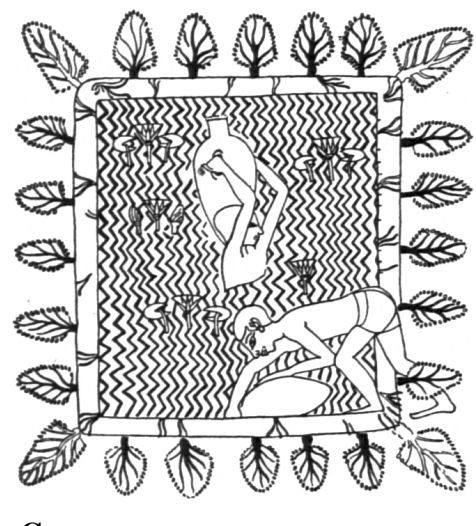

$\mathrm{C}$
B

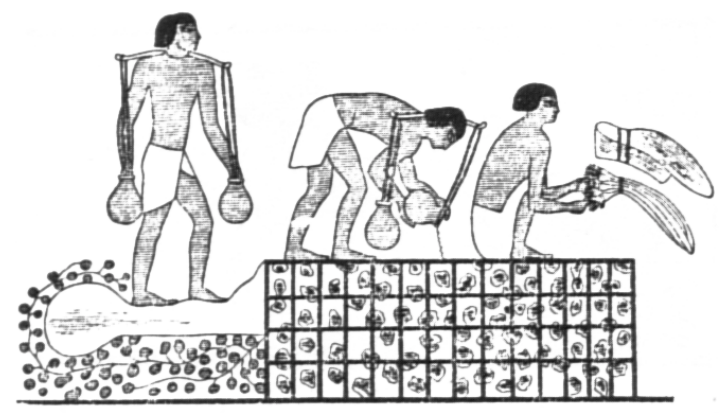

D

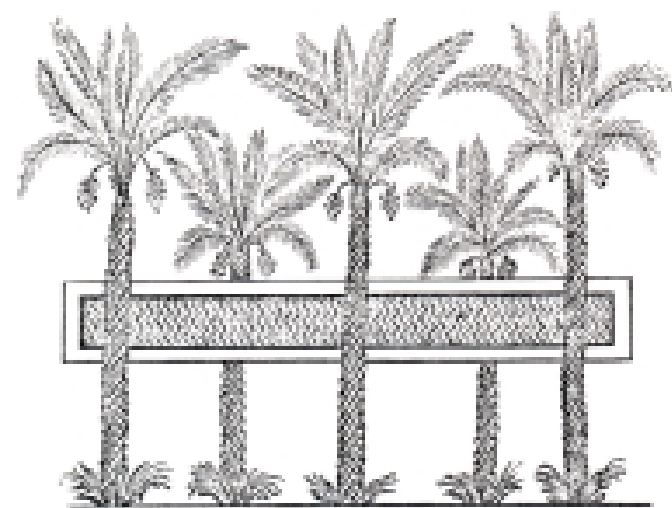

Fig. 3. Irrigation technology in ancient Egypt.

A. Drawing water in pots from a lily pond. From a tomb at Thebes, Egypt. ca 1450 BCE. Source: Singer et al, 1954, Fig. 343.

B. Irrigating and harvesting in a vegetable garden. Gardeners carry pots attached to a yoke and pour water into checkerboard furrows; another ties onions into bundles. From a tomb at Beni hasan, Egypt. ca. 1900 BCE. Source: Singer et al., 1954, Fig. 360.

C. Irrigation of a palm orchard by a shaduf, using a water-lifting device consisting of a beam holding a long pole in which a bucket is suspended at one end and a large lump of clay acts as a counterpoise. The water is funneled to a mud basin at the foot of the palm. From a Tomb at Thebes, ca. 1500 всE. Source: Singer et al., 1954, Fig. 344.

D. Date palm with water storage pond in a distorted perspective. Source: E. Hyams, 1971, p. 18.

waters ran through a series of regulated sluices into each basin flooding the land to a depth of 0.3 to $1.8 \mathrm{~m}$. The water could be held for a month or more; the surplus was drained to a lower level and then returned to canals which emptied into the Nile. The advantage of basin irrigation was that no further irrigation was needed for a winter crop of wheat, barley, or flax and the silt rich in organic matter and phosphates made fertilization unnecessary.

Ponds were important for irrigation of fruit trees and for ornamental gardens (Fig. 3D; Fig. 12A,B,C,E,F). Shallow wells were 4 to $35 \mathrm{~m}$ in depth; deeper artesian wells were dug up to $380 \mathrm{~m}$. Vegetables, flowers, vines, and fruit trees were grown near the rivers, by the banks of canals, and in prized gardens. These horticultural crops required constant and controlled irrigation during the 
spring and summer drought. At first irrigation was carried out manually with pots dipped in the river, carried on the shoulders with yokes, and poured into field channels (Fig. 3B). By the New Kingdom, the shaduf, a balanced counterpoise, became the irrigating mechanism for gardens (Fig.1D, $12 \mathrm{~F})$

\section{Cultivation Technology}

The basic tools of agriculture, the ax, the hoe, the plow, are independent Egyptian inventions. The prototype hoe can be seen as a modification of a forked branch, while the more developed form has a hafted wooden blade (Fig. 4A,B). The plow was at first a modification of the hoe, originally drawn through the ground, perhaps first by a man with a rope, but by the Old Kingdom by a pair of oxen (Fig.4C,D). Later metal plowshares were added. In the New Kingdom handles were lashed by ladder-like cross pieces and the shaft was bound to a double yoke over the oxen's horns (Fig. 4D).

Sowing followed plowing. Often the sower scattered seed in front of the plough, so that the oxen treaded it in while fine seed as flax was shaken directly into the furrows (Fig. 4D). If the seed was sown after flooding, sheep, goats, or swine, were driven to tread in the seed (Fig. 4E). Seeding technology was described by Herodotus as follows: “... for they have not the toil of breaking up the furrow with the plough, nor of hoeing, nor of any other work which all other men must labor at to obtain a crop of corn; but when the river has come of its own accord and irrigated their fields, and having irrigated them has subsided, then each man sows his land and turns his swine into it; and when the seed has been trodden into by the swine he waits for harvest time: then ... he gathers it in." (Durant, 1954).

Surveyors measured fields for purposes of tax collection (Fig. 5A). Large stones were used to establish property boundaries (Fig. 5B). Moral teachings included the maxim: Remove not the landmark on the boundaries of the sown, nor shift the position of the measuring-cord. Covet not a cubit of land, nor throw down the boundaries of the widow...Better a bushel that God giveth thee, than five thousand obtained by force.

\section{Harvest and Postharvest Technology}

Harvest and postharvest handling of grain were favorite themes in Egyptian art (Fig. 6). Early sickles, used to cut wheat, had flint teeth set in a wooden or bone haft followed by curved sickles with a short hand-grip (Fig. 6A,B) Metal sickles were common in the New Kingdom. Wheat was bound into sheaves and loaded onto donkeys for storage (Fig. 6C or later carried in net baskets. Fruit was collected and packed in shallow baskets, artfully arranged (Fig. 7).

Evidence of grain storage dates to Neolithic times in buried baskets or earthenware jars. Later the storage of grain and other provisions became a state function and communal silos and granaries were constructed (Fig. 8). In the temple of Abu Simbel built by King Rameses II (XVIII dynasty) the following words are caved: "I (the God Ptah) give to thee (Rameses II) constant harvests, to feed the Two Lands at all times; the sheaves thereof are like the sand of the shore, their granaries approach heaven, and their grain-heaps are like mountains." (Darby et al., 1976). The Roman world considered Egypt the "breadbasket of the world."

\section{Viticulture}

Grapes were much appreciated in ancient Egypt. There are abundant depictions of grapes, grape culture, and wine making (Fig. 9). Pliny reports that vines were grown directly on the field surfaces but there are many representations of trellises and arbors (Fig. 9A). The round arbor was a common feature between the New Kingdom and the Graeco-Roman Period. Greek authors confirmed that various cultivars of Vitis vinifera were developed in Egypt. The biblical literature is rich with allusions to grapes and wine. In Joseph's dream, the Pharaoh's chief butler narrates (Genesis 40, 9-10):. "behold, a vine was before me, and in the vine were three branches; and it 
A

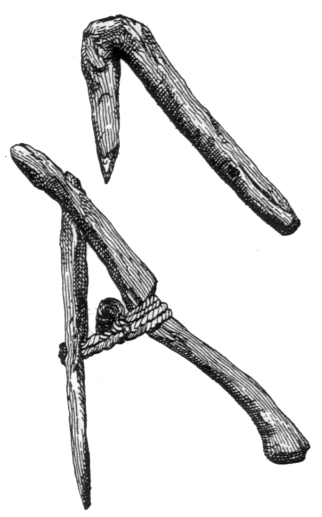

B

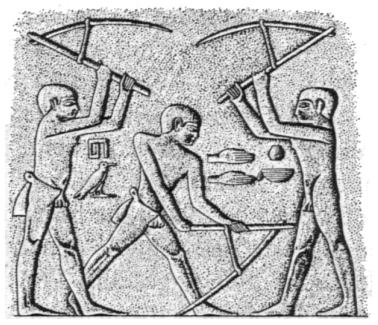

C

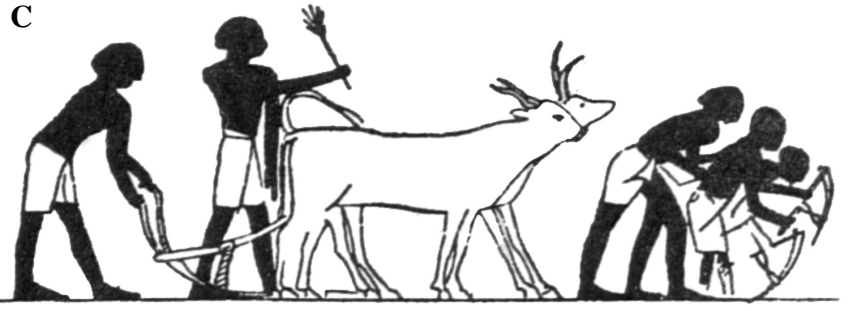

D

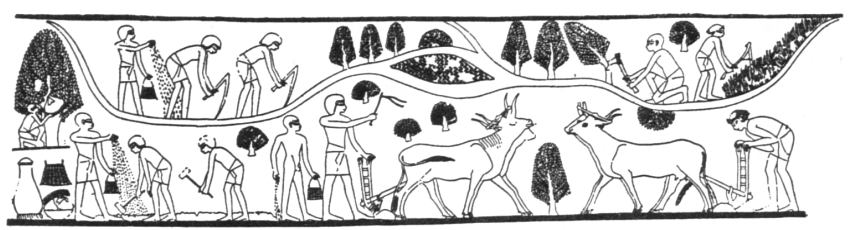

$\mathbf{E}$

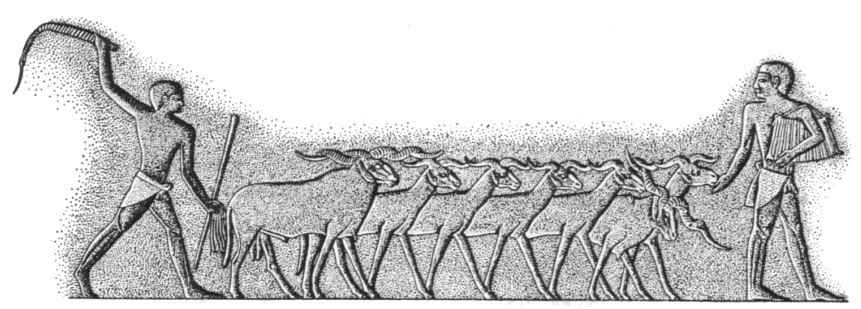

Fig. 4. Cultivation technology in ancient Egypt.

A. Development of the hoe. (Top) Primitive hoe cut from a forked branch. (Bottom) A more developed form with hafted wooden blade. Both Middle Kingdom (2375-1800 BCE). Source: Singer et al., 1954, Fig. 350.

B. Soil preparation by hoeing; from a Tomb at Ti at Saqqara, ca. 2400 вCE. Source: Singer et al., 1954, Fig. 350.

C. Plowing and hoeing; from a tomb at Beni Hasan, ca. 1900 вCE. Source: Singer et al., 1954, Fig. 43.

D. Land reclamation. Trees are being cut in land clearing; clods are broken with mallets, soil is plowed, seed is sown on prepared ground. Note ladder like cross pieces on plow handle and shaft bound to a double yoke over the oxen horns. Source: Singer et al., 1954, Fig. 351.

E. Seed is treaded by sheep driven across a field. The sower offers them a handful of grain to lure them on while another drives them with a whip. From a tomb at Saqqara, Egypt, ca. 2400 BCE. Source: Singer et al., 1954, Fig. 353.

was as though it budded, and her blossoms shot forth, and the clusters thereof brought forth ripe grapes"

Grapes were preserved by drying. Raisins became favorite foods in cooking, were considered to have medicinal properties, and were at one time used as a drying aid in embalming. 


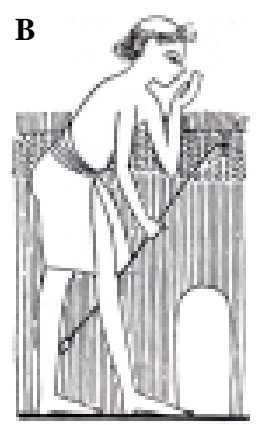

Fig. 5. Surveying fields.

A. Surveyors measuring a field, probably to determine tax. From a tomb at Thebes ca. 1400 всE. Source: Singer et al., 1954, Fig. 354.

B. Oath taken on a boundary stone: I swear by the great god that is in heaven that the right boundary stone has been set up. ca. 1400 BCE. Source: Singer et al., 1954, Fig. 355.

\section{Ripening Induction}

One of the most interesting examples of horticultural technologies incorporated by the Egyptians was the promotion of ripening in the sycomore fig. The fig occurs spontaneously in the savannas of eastern Central Africa and in Yemen where they reproduce by seed although propagation is easily carried out by cuttings (Galil 1968). Fruit set depends on pollination by a wasp (Ceratosolin arabicus) which enters the fruit. The sycomores were introduced to Egypt more than 3000 years BCE but not the wasp, so the fruits were seedless and dropped prematurely, or if ripened naturally were full of insects and, thus, inedible.

A system of ripening parthenocarpic fruit was developed that involved scraping or wounding of the immature fruit. Gashing of the fruit induces speedy growth in three to four days and the figs increase seven-fold in weight and volume, a process now shown to be an ethylene response. The wounding process yields an induced parthenocarpic fruit that matures before the development of insect pests which makes the fig inedible. Metal scrapers and gashed fruit have survived and are clearly illustrated in a bas relief in Thebes.

The process in Egypt was described by Theophrasus as follows: [The sycomore fruit] cannot ripen unless it is scraped, but they scrape it with iron claws; the fruit thus scraped ripens in four days. The sycomore tree became highly prized for shade and timber, and the fruit, although not superlative, was esteemed. Commonly used for funeral offerings, the tree became sacred.

The fruits reached ancient Israel where they were known as the food of the poor. They are referred to in the Bible in a famous passage referring to the occupation of the prophet Amos. According to the King James Version of the Hebrew Bible, Amos states: I was no prophet, neither was I a prophet's son, but I was a herdsman and gatherer of sycomore fruits (Amos 7,14). However, translation is in error as the Hebrew Boless Shikmim should be translated as "gasher of sycomores." In the Greek translation of the Hebrew Bible, known as the Septuaginta (200 BCE in Alexandria), the key words are Knizon Sycaminna or "piercer of sycomore." The English translators obviously could not understand the concept of gashing the fruit and stretched the translation. Contemporary Israeli sycomores produce fruit without gashing, but it is likely that in ancient times the same clones were used as found in Egypt. 


\section{Pest Control}

Predation by insects, rats, birds, hippopotami in addition to tax collectors are poignantly reported from ancient texts (Durant, 1954) : "Dost thou not recall the picture of the farmer when the tenth of his grain is levied? Worms have destroyed half the wheat, and the hippopotami have eaten the rest; there are swarms of rats in the fields, the grasshoppers alight there, the cattle devour, the little birds pilfer; and if the farmer loses sight for an instant of what remains on the ground, it is carried off by robbers; moreover, the thongs which bind the iron and the hoe are worn out, and the team has died at the plough. It is then that the scribe steps out of the boat at the landing-place to levy the tithe, and there come the Keepers of the Doors of the (King's) Granary with cudgels, and Negroes with ribs of palm-leaves, crying, "Come now, come!" There is none, and they throw the cultivator full length upon the ground, bind him, drag him to the canal, and fling him in head first; his wife is bound with him, his children are put into chains. The neighbors in the meantime leave him and fly to save their grain"

Use of sling shots to chase away birds is shown in Fig. 7C. Ancient Egyptians also practiced biological control; many insectivorous birds were protected by the state.

\section{Biotechnology: Bread and Wine}

The beginnings of biotechnology are directly traced to the manufacture of bread and wine. The harvest, threshing, grinding of grain to flour and subsequent sieving are abundantly illustrated (Fig. 6). Grinding of grain was handled with a hand mill called a saddle quern (Fig. 6F) by the housewife, but eventually grinding was carried out on a large scale by millers. Fermentation by the use of leaven, a mass of yeast, was a development that changed the making of bread (Fig. 6G). By $1200 \mathrm{BCE}$, over 30 different forms of bread and cakes were mentioned.

Alcoholic fermentation was carried out in pots with bread or flour to make beer, or sugary fruit juices, particularly grape but also dates and pomegranates to make wine, and with honey to make mead. Wine is specified as early as the first dynasty and was associated with Horus, the falcon-headed god, son of Isis, the Great Mother, loyal sister and wife of Osiris, god of the beneficent Nile. The first Pharaoh called his vineyard "The Enclosure of the Beverage of the Body of Horus" resonating with the subsequent relation of wine to the blood of Jesus Christ in the Eucharist. About 1200-1500 BCE the complete wine making process is illustrated (Fig. 9), beginning with grape harvest from arbors, treading by workers maintaining their balance by holding hanging cords attached to a frame, and the squeezing of the sediment collected in cloth bags, with fermentation carried out in jars (amphorae). After fermentation wine vessels were sealed with plugs of

Fig. 6. Harvesting and handling grain.

A. Reaping grain and tying sheaves. Tomb at Mena at Thebes, ca. 1420 BCE. Source Darby et al., 1976, Fig. 11.4c.

B. Reaping wheat in New Kingdom. Heads are cut short and cast into a large net, from a tomb at Thebes ca. 1420 вCE. Source: Singer et al., 1954, Fig. 357.

C. Harvesting wheat in Old Kingdom. Heads are bound into sheaves and loaded onto donkeys. From a tomb at Saqqara, ca. 2400 BCE. Source: Singer et al. 1954, Fig. 359.

D. Oxen threshing grain. Tomb of Mena at Thebes ca. 1420 BCE. Source: Darby et al., 1976, Fig. $11.4 \mathrm{~b}$.

E. (Above) Winnowing grain by tossing the grain into the air with wooden scoops. (Below) Husked grain is measured in bushels before storage. From a tomb at Thebes ca. 1420 всE. Source: Singer et al., 1954, Fig. 358

F. Grinding wheat in a saddle-quern. ca. 2500 вСE. Source: Singer et al. 1954, Fig. 176.

G. A bakery in Rameses III's tomb at Thebes showing cakes of various shapes. Source: Darby et al., 1976, Fig. 12.14. 
A

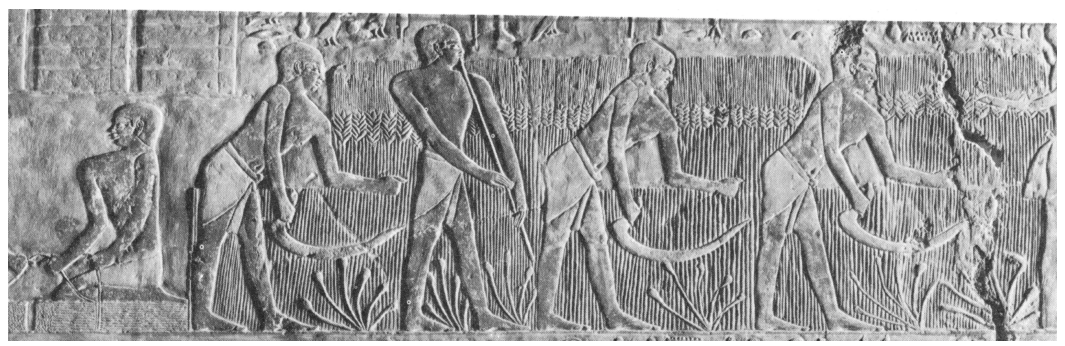

B

C
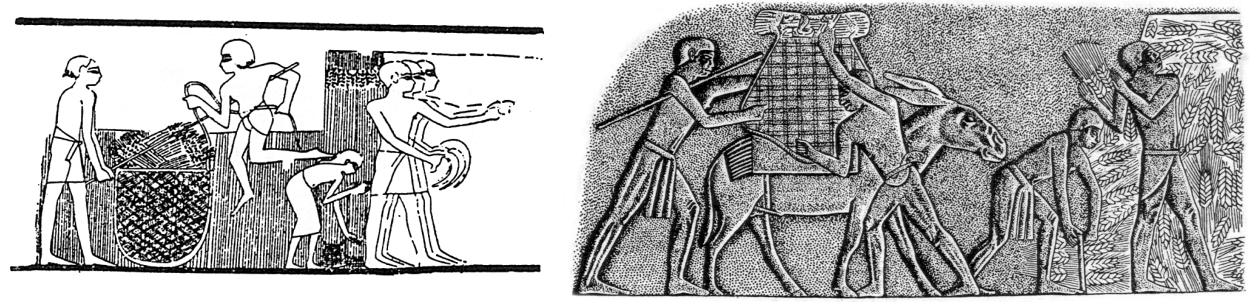

D

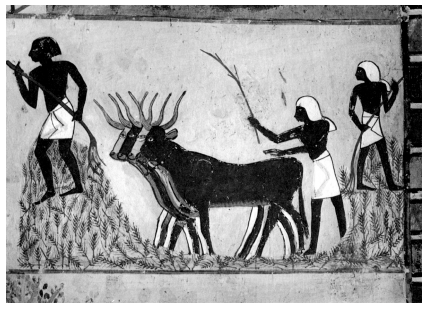

E

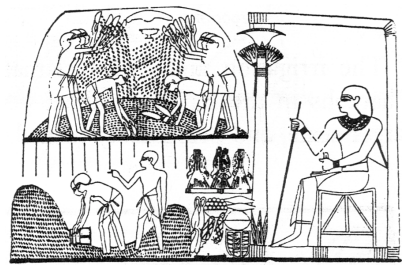

F

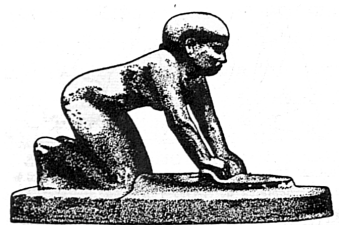

G

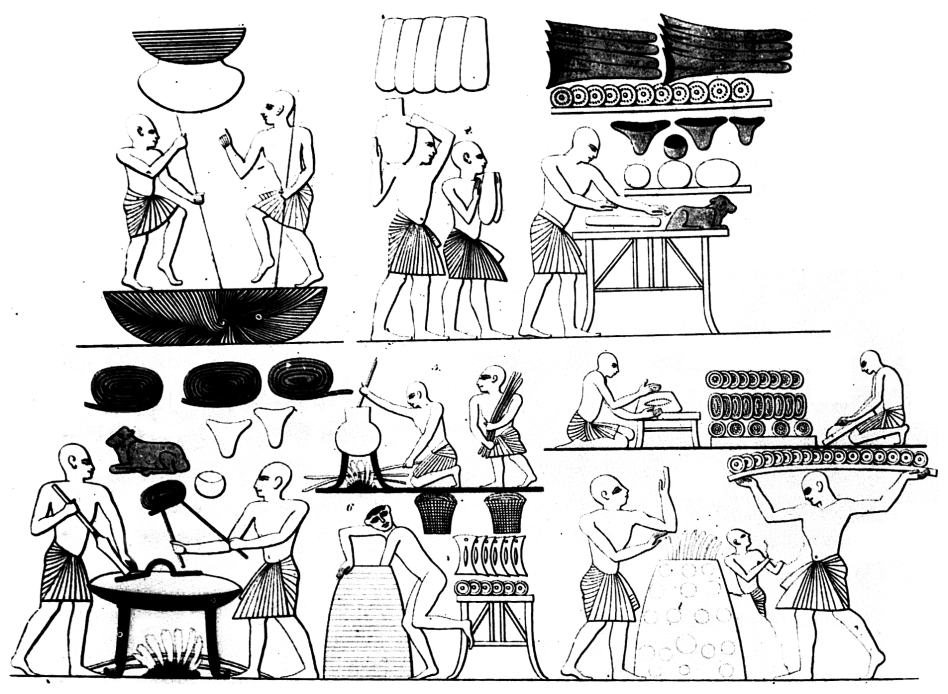


A

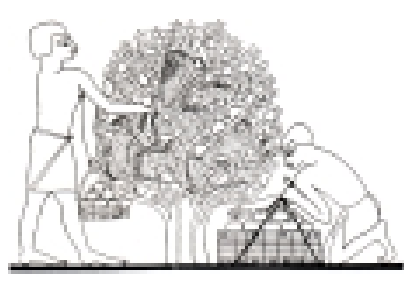

D

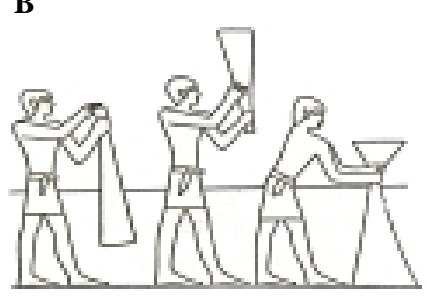

C

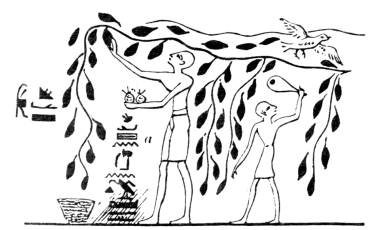

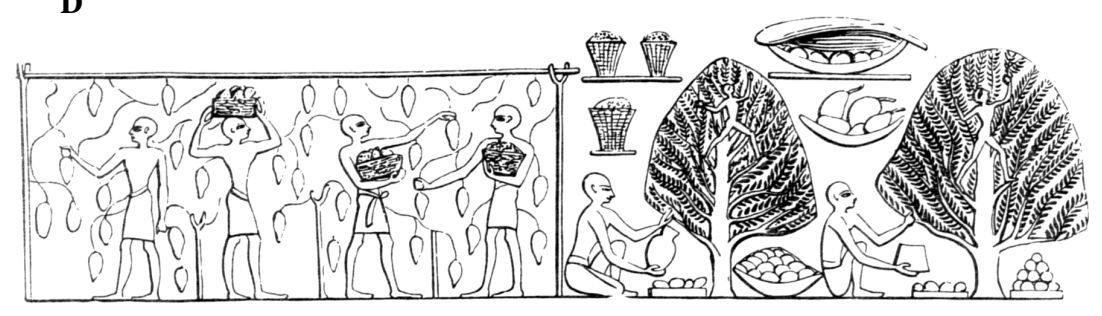

Fig. 7. Harvesting fruit crops and flax.

A. Gathering figs in shallow baskets while tame baboons cavort in the tree. From a tomb at Beni Haxan, Egypt, ca. 1900 BCE. Source: Singer et al., 1954, Fig. 362.

B. Harvesting and binding flax in sheaves. From the tomb of Hetepet, Old Kindom. Source: Singer et al., 1954, Fig. 352.

C. A worker harvests pomegranates while a boy chases away a bird with a slingshot. Source: Hyams, 1971, p. 13.

D. Harvesting fruit from trellis and free standing trees. Source: Hyams, 1971, Fig. 14.

straw and clay designed to prevent bursting from gas accumulation, and impressed with official stamps containing the year of the king's rule, the district, the town, and the name of the wine (Fig. 9F). Wines were mixed by siphoning (Fig. 9G). Taxes were levied on imported and exported wine. By the Graeco-Roman periods there were literally hundreds of wine types from grapes indicating intense genetic selection.

\section{Plant Exploration}

Pharaohs were sophisticated horticulturally. From foreign campaigns they brought back exotic trees and plants to be grown in their palace or temple gardens (Fig. 10). Queen Hatshepsut, organized a plant expedition delivering living myrrh-trees from Punt (Northeastern Africa) for the terraced gardens of her Temple at Deir el-Bahri in 1500 BCE (Fig. 10B). Her nephew Thothmes III (1450 BCE) had the curious plants brought from Syria carved upon the walls of the Temple of Amen in Karnak (Fig. 10C) from which iris can be recognized. Rameses III (1198-1166 BCE) made "great vineyards; walks shaded by all kinds of sweet fruit trees, a sacred way splendid with flowers from all countries, with lotus and papyrus as numerous as the sand." (Huxley, 1978,1998)

\section{Gardens and Ornamental Horticulture}

Gardens in Egypt represent the beginnings of agriculture. They originated on the edge of the desert where the natural vegetation is sparse. There was no landscape to copy except that of the 


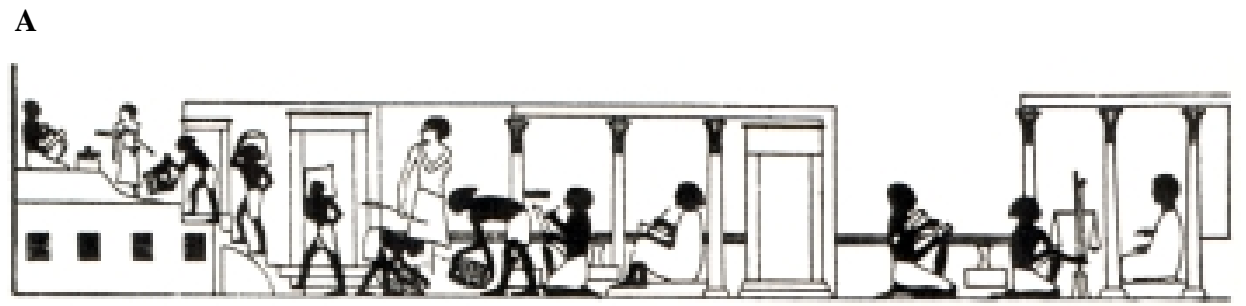

B

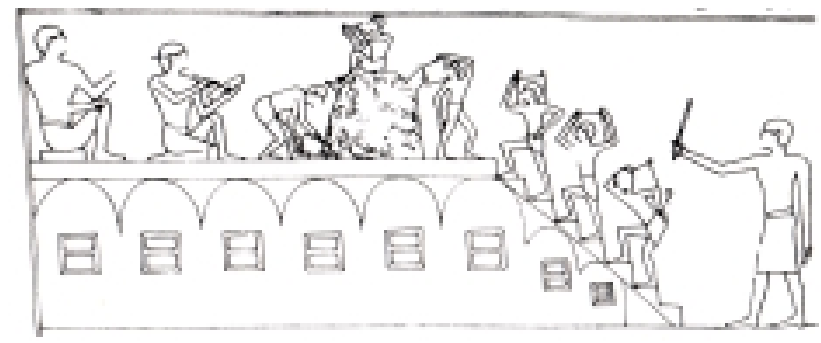

C

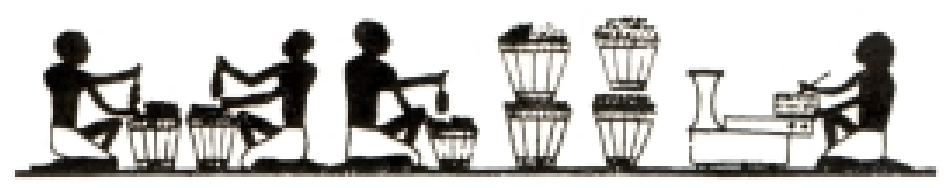

Fig. 8. Storage.

A. Storing the harvest and quality control; note scribe and driver with whip. From a tomb at Beni Hasan, Egypt. ca. 1900 всE. Source: Singer et al., 1954, Fig. 26.

B. Workers carry grain into silos while scribes register the amount. Tomb of Antefoker at Thebes, Middle Kingdom. From Darby et al., 1976, Fig. 11.3.

C. A scribe checks the storing of raisins. From a tomb at Beni Hasan, ca. 1900 BCE. Source:

Singer et al., 1954, Fig. 26.

oasis. Thus, the first garden can be thought of as an artificial, protected oasis and such gardens still exist (Fig. 11). Later gardens surrounded by walls were often terraced, containing enclosed pools to provide the "oasis" feeling and containing water plants (Fig. 12). The gardens were replete with statuary and ornamental columns (Fig. 12D). Plantings became ordered and set in straight rows because of irrigation requirements and the flatness of the land (Fig. 12EF). Irrigation canals were a common feature. Plants were treated architecturally; trained on lattice structures to artificial shapes (referred to as arbors, bowers, or pergolas). Fruit trees, palms, and vines in symmetrical arrangements were common garden plants providing food and shade.

Egyptians gardens are the forerunners of our present-day formal gardens which use plants as architectural elements. Because there was essentially no natural landscape, the Egyptians created one based on straight lines and symmetry. They represent human domination over plants and an ordered, artificial environment. It is the antithesis of the naturalistic gardens of Asia which strove to emulate the natural scenery. 
Fig. 9. Grape harvest and wine making.

A. Grapes are collected from a round arbor and workers crush grapes by stomping while balancing on cords hanging from a frame. Wine is stored in amphorae. From a tomb at Thebes, Egypt, ca. 1500 всE. Source: Singer et al., 1954, Fig. 185.

B. Manufacture and registration of wine. Late Pharaonic-Ptolemaic period, Tomb of Petosiris. Source Darby et al., 1976, Fig. 14.15.

C. Pressing grapes in an early Egyptian bag press where the bag is squeezed by poles. From a tomb at Saqqara, ca. 2500 BCE. Source: Darby et al., 1976, Fig. 14.4.

D. Expressing juice of grapes by twisting a bag press in which the ends are held apart in a frame. An inspector tests the cloth for holes. From a tomb at Beni Hasan, ca. 1500 BCE. Source: Darby et al., 1976, Fig. 14.3.

E. Preparation of wine showing both foot pressing and a bag press. From a mural in the palace of Thebes of the reign of Amenopsis II, 1450-1425 BCE. Source: Goor and Nurock, 1968, p. 20.

F. Wine jars found in the tomb of Tut-Ankh-Amon. The lid beards the stamp of the Pharaoh. In the jar on the right note the safety opening made in the lid to allow gases out, later closed with a plug of clay. Source: Darby et al., 1976, Fig. 14.8,9.

G. Mixing wines by siphoning, perhaps at a banquet. Source: Darby et al., 1976, Fig. 14.7.

\section{Conclusions}

A study of Egyptian history underscores the ancient origins of agriculture. The modern world is in debt to this great civilization which contributed many of our basic agricultural innovations: cultivation and irrigation technology and the horticultural arts. Ancient Egyptian agriculture is also shown to be the Mother of Science providing the resources to enable the construction of vast public works and temples and the basic inspiration to progress from mathematics to chemistry and from medicine to metallurgy. Despite advances in technology, Egyptian culture became ever increasingly conservative and traditional, so that continued advances were thwarted. Progress was hampered by the restraints of a rigid society first run by an uneasy alliance between nobles and priests, and when racked by internal instability, deteriorating to a stagnant theocracy. The decline was evident about 1000 BCE and Egypt succumbed to pressures from invading cultures: Phoenician, Libyan, Ethiopian, Assyrian, Persian, the armies of Alexander, Roman legions, and the proselytizing desert warriors from Arabia who introduced a new religion and eliminated the old. After the $15^{\text {th }}$ century, Egypt was controlled by the Ottoman Turks and later influenced by the colonial power of France and England. It is hoped that an independent Egypt will be spurred on by the archeological evidence that dominates the landscape and is continually uncovered. These ancient relics, ignored for thousands of years, should be an inspiration to restore the glory in innovation, art, and agriculture that was the hallmark of ancient Egypt.

\section{$\underline{\text { References }}$}

Berrall, J.S. 1966. The Garden: An Illustrated History. Viking Press, New York.

Darby, W.J., Ghalioungui, P., and Grivetti, L. 1977. Food: The Gift of Osiris. 2 vol. Academic Press.

Durant, W. 1954. The Story of Civilization. Part I. Our Oriental Heritage. Simon and Schuster, New York.

Galil, J. 1968. An ancient technique for ripening sycomore fruit in East-Mediterranean Countries. Econ. Bot. 22:178-191.

Hyams, E. 1971. A History of Gardens and Gardening. Praeger, New York.

Huxley, A. 1978, 1998 rev. An Illustrated History of Gardening. The Lyons Press, New York.

Janick, J. 1979. Horticulture's ancient roots. HortScience 14: 299-313.

Khattab, H. undated (2000?) Ancient Egyptian Agriculture Museum brochure. Cairo. 
A

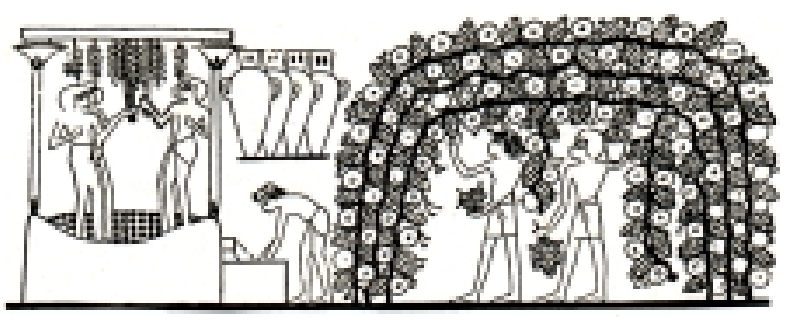

B

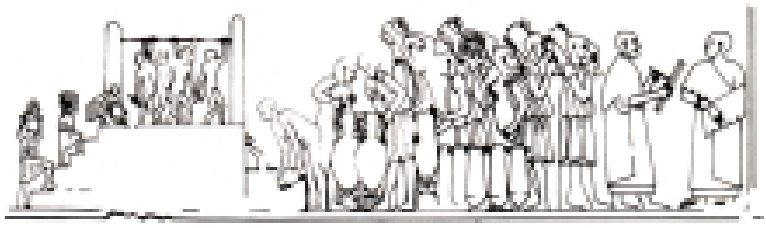

C

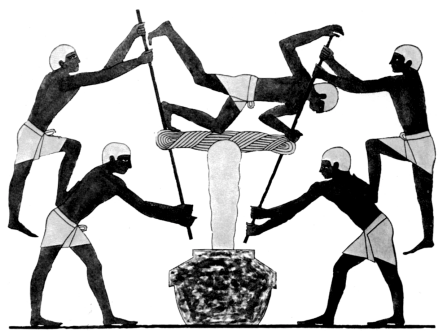

D

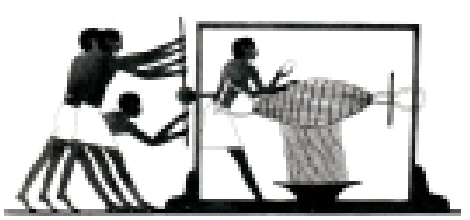

$\mathbf{E}$

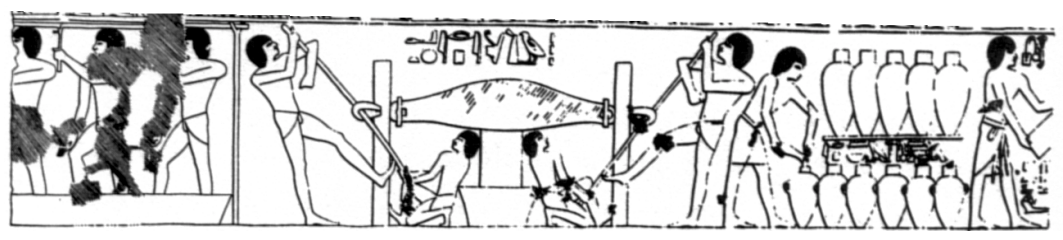

$\mathbf{F}$

G
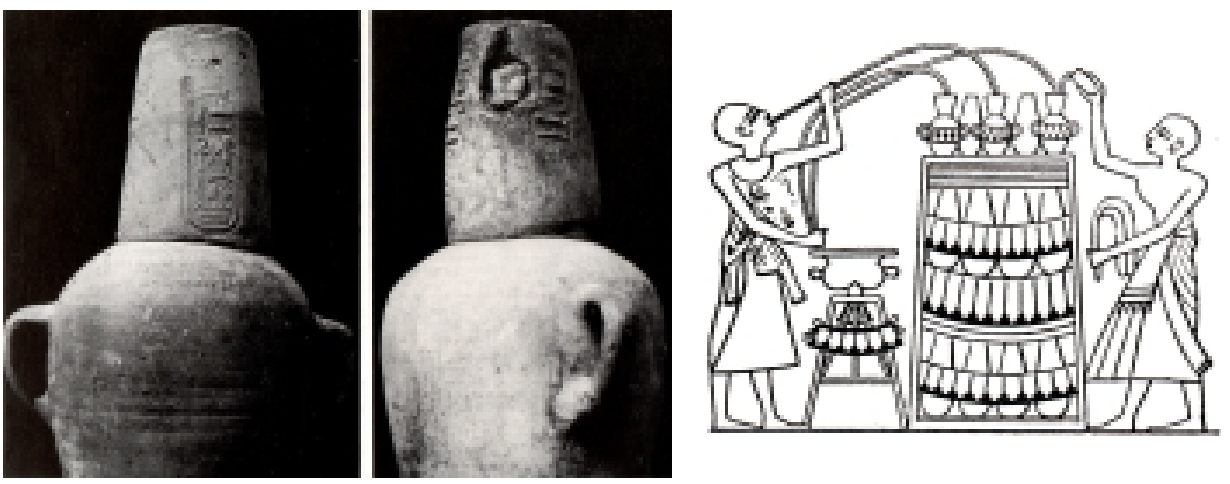

Smith, B.D. 1995. The Emergence of Agriculture. Scientific American Library, W.H. Freeman \& Co., New York.

Singer, E., Holmyard, E.J., and Hall, A.R. 1954. A History of Technology. Vol 1. Fall of Ancient Empires. Oxford University Press, London.

Thacker, C. 1979. The History of Gardens. University of California Press, Berkeley.

Wright, R. 1934. The Story of Gardening. Dodd, Meade \& Co., New York. 
A

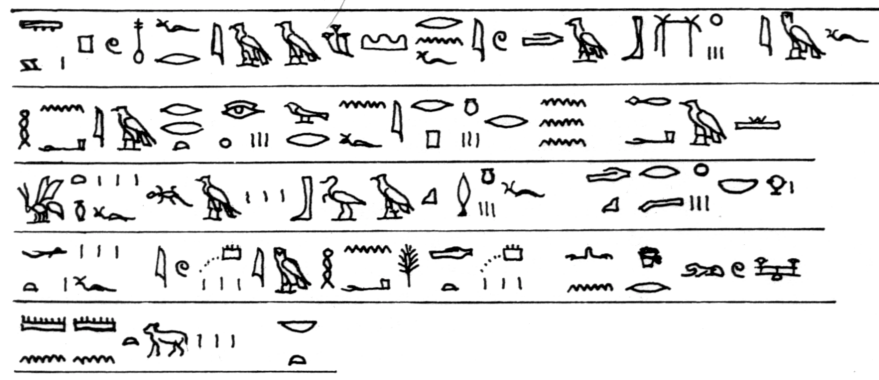

C

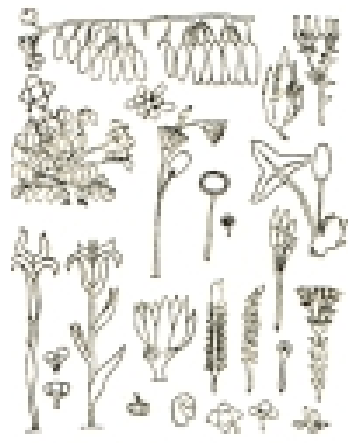

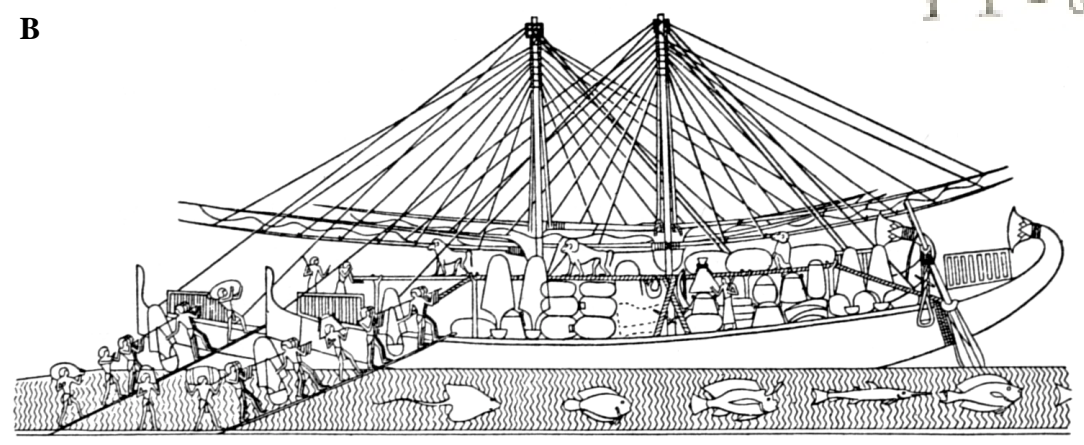

Fig. 10. Plant exploration.

A. An epistle in which the Egyptian scribe Sinuhe penned the following description about Yaa, the name for Israel (ca $2000 \mathrm{BCE}$ ). It was a goodly land called Yaa. Figs were in it and grapes, and is wine was more abundant than its water. Plentiful was its honey, many were its olives; all manner of fruits were upon it trees. Source: Good and Nurock, 1968, p. 2.

B. Ships of Queen Hatshepsut's fleet lading at Punt (northeastern coast of Africa) with exotic merchandise for Egypt. From a temple at Deir el-Bahri, Egypts, ca. 1500 BCE. Note the tame baboons, the marine character of the fishes depicted, and the carriage and storage of growing incense plants. Source: Singer et al., 1954, Fig. 32.

A. An early botanical collection. Strange plants and seeds brought back from Syria by Thothmes II, as they were carved on the walls of the temple of Karnak, Egypt, ca. 1450 BCE. Source: Singer et al., 1954, Fig. 32.

Fig. 11. Oasis at El Tor, Sinai peninsular. Source: J. Janick, photo.

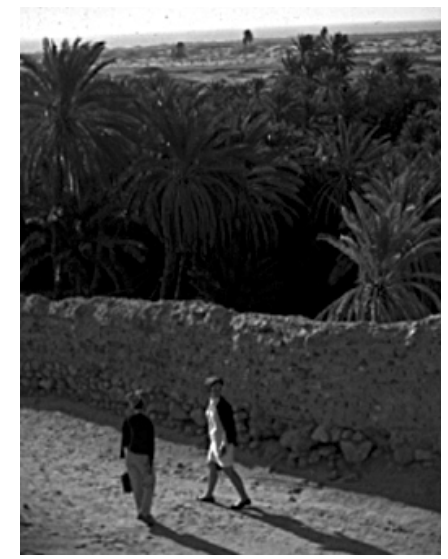




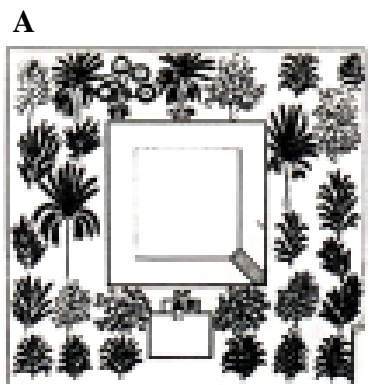

B

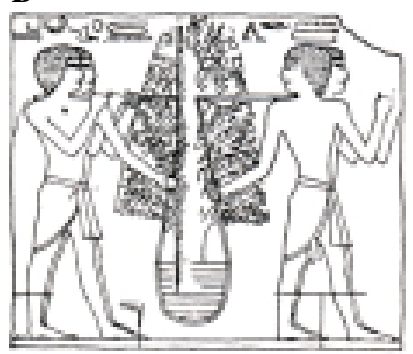

$\mathbf{E}$

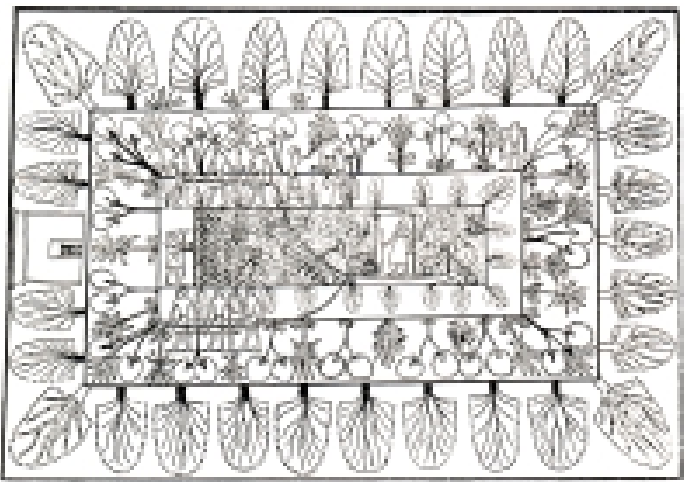

C

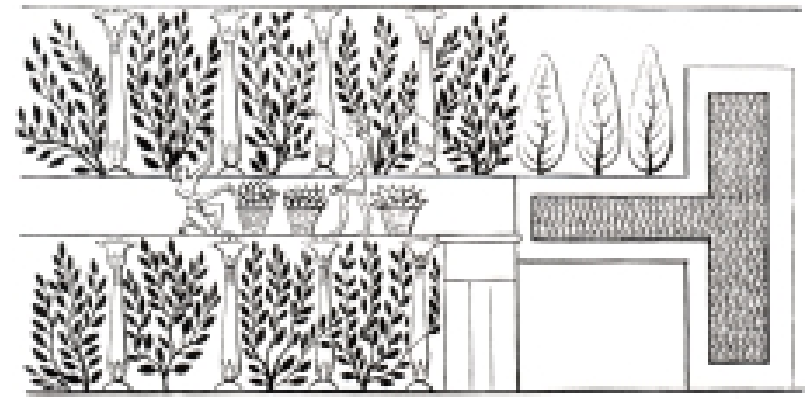

D

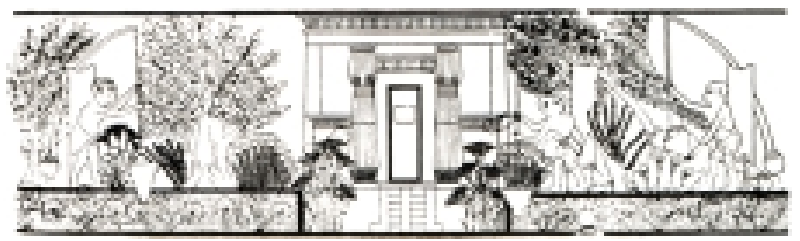

$\mathbf{F}$

Fig. 12. Ancient Egyptian garden scenes.

A. Randomly-placed trees growing within a square enclosure surrounding a square pool. Carving from the tomb of Akhnaton (18 ${ }^{\text {th }}$ dynasty). Source: Thacker, 1979, Fig. 6.

B. Four workers transporting trees for transplanting. Source: Wright, 1934.

C. Harvesting pomegranates in a formal planting interspersed with ornamental columns next to a T-shaped pool. Source: Hyamns, 1971, Fig. 13.

D. Garden planted with fig, olive trees and flowering plants containing a pavilion with steps leading down to the water, being irrigated by a row of shadufs. From a tomb at Thebes, ca. 1300 вCE. Source: Singer et al., 1954, Fig. 345.

E. Formal Egyptian garden. The lotus pool, on which the statue of the vizier Rekhmire is being towed in a boat, is faced at one end by a pavilion or summerhouse. Around the pool grow doum palms, date palms, acacias, and other trees and shrubs. From the tomb of Rekhmire at Thebes ca. 1450 BCE. Source: Singer et al., 1954, Fig. 361.

F. Garden plant for a wealthy Egyptian estate. Note two types of palms: single trunk $=$ date palm, bifurcated trunk = doum palm. Source: Berrall, 1966, p. 120. 